\title{
The Impact of Barsha Pump Use Towards Access and Control to Financial Management of Farmers in Waingapu, Sumba Island in Indonesia
}

\author{
Kadek Wiwik Indrayanti Dewi Astutty Mochtar \\ University of Mereka Malang, East Java, Indonesia
}

\begin{abstract}
Sumba in one of the driest island in Indonesia where community is suffering lack of water for household as well as agriculture purposes, particularly in the dry season. To solve the problem, Max Waingapu Radio Foundation has installed the Barsha pump, which is water-powered technology instead of fuel based and the impacts of the project are not yet evaluated. Therefore, this study is aming to investigate the impacts of the use of Barsha pumps on the access and control in the financial management mechanism among the farming community. This study carried out two times in-depth interviews as well as focus group discussions in nine villages of Waingapu. The results show that the benefits from the project opened possibilities for farmers to irrigate their fields and produce crops during the dry season and to increase income as well as standards of living. Moreover, the most important findings is that the access and control of financial management of farmers are quite impressing, especially the female farmers.
\end{abstract}

Keywords: Farmers, Barsha pump, financial management

DOI: $10.7176 / \mathrm{JLPG} / 88-03$

Publication date: August $31^{\text {st }} 2019$

\section{A. Introduction}

Sumba is one of the driest regions in Indonesia, and a challenge for the people who mostly make their living from farming or gardening. The biggest problem for farmers in Sumba is the need for water which are used to supply household needs and irrigate their fields during the dry season. Women must walk $12 \mathrm{~km}$ to collect water from the river and wells and wash their clothes once a week. ${ }^{1}$ Several actions have been taken to prevent water scarcity by the Ministry of Environment and Forestry, in collaboration with BAPPEDA NTT through the SPARC project and implemented by a local NGO, Koppesda, supervised by the UNDP. However, the results are still in need of further evaluation, and generally a project depends on the availability of funds and is not sustainable. ${ }^{2}$

For decades, villagers residing around the banks of the Waikudu and Mbatakapidhu rivers, East Sumba Regency, suffers heavily at the arrival of dry season. Although plantations are available along the riverbanks, which are naturally located close to water source, villagers are unable to irrigate plants due to the height of the riverbanks with the lowest water level reaching as high as two meters. This condition certainly provides difficulty to water the fields regularly when trying to plant vegetables along the riverbanks. Before this project was carried out, some farmers around the village often operate water-sucking machines which uses gasoline to bring water into their fields. The fuel must be purchased from the city of Waingapu, which is about 30 kilometers away, and some villagers need to take a motorcycle taxi as they are not in possessions of any vehicle. ${ }^{3}$ vehicle. ${ }^{3}$ Likewise, the portrait of women's role in agriculture in general shows minimum difference. Female farmers have quite limited access to loans and the provision of land is still very formal. The land tenure pattern is still controlled by husbands, though agricultural activities are given to women. ${ }^{4}$ Women's participation is still restricted and they possess no authority in the decision-making process regarding agricultural business. Agricultural tools and machinery are highly accessed and mostly designed to be used for male farmers, but not necessarily for female farmers. ${ }^{5}$ The initial study conducted by Indrayanti ${ }^{6}$ showed that access, participation, and and the opportunity for female farmers to express themselves were still far from expectations. It is in line with the study conducted by Hastuti and Diah Respati, who stated that women were more active in domestic work, but possess restricted opportunity for self-improvements. ${ }^{7}$ Generally, women play roles and hold responsibilities

\footnotetext{
${ }^{1} \mathrm{http}$ ://kupang.tribunnews.com/2018/08/07/heinrich-dominggus-dengi-ingin-petani-sukses

$2 \mathrm{https}$ ://undpid.exposure.co/pompa-air-yang-mengubah-kehidupan-di-sumba-timur

${ }^{3}$ http://maxfmwaingapu.com/2017/08/pompa-barsha-bantu-petani-di-musim-kemarau

${ }^{4}$ Asma Luthfi. 2010. Akses dan Kontrol Perempuan Petani Penggarap Pada Lahan Pertanian PTPN IX Kebun Merbuh. Komunitas 2 (2) (2010): 74. http://Journal.unnes.ac.id/nju/index.php/komunitas

${ }^{5}$ Sri Walny Rahayu dkk. 2009. https://www.academia.edu/29818839/analisis studi pada instansi pemerintah sektor pertanian Province Aceh. Accessed on 30 September 2018.

${ }^{6}$ Indrayanti, Kadek. 2017. Independent Lecturer's Research.

${ }^{7}$ Hastuti dan Respati, Dyah. (2009). Model Pemberdayaan Perempuan Miskin Berbasis Pemanfaatan Sumberdaya Perdesaan Upaya Pengentasan Kemiskinan di Perdesaan (Studi di Lereng Merapi Daerah Istimewa Yogjakarta). Jurnal Universitas Negeri Yogjakarta.
} 
in the domestic sphere, but rarely take roles in decision making and carving policies and implementing projects for irrigation. ${ }^{1}$ Similar role amomg female also happen among Malawi farmer ${ }^{2}$.

For farmers who plan to remain in agriculture, gender roles have impacts on both farming and livelihood systems. ${ }^{3}$ Women farmers in particular may not have the same power as men farmers to make important decisions relating to changing agricultural practices. ${ }^{4}$

One factor of gender issues in Indonesia is the presence of gender inequality and the inadequacy of the justice system. This can be observed from the limited involvement of women in decision-making processes in public policy. This is a portrait in almost every social institutions and agencies. The low access and opportunity for women to obtain various resources results in the low benefits enjoyed by women in development processes. To reduce this gap, every policy and program should integrate women's and men's experiences, aspirations, needs, and problems into programs and actions, starting from planning, execution, and evaluation processes.

The legal basis for the importance of Gender Mainstreaming to be implemented in all aspects is listed in the 1999 Broad Guidelines of State Policy (GBHN), Law Number 25 Year 2000 concerning the National Development Program - PROPERNAS 2000-2004, and confirmed in the Presidential Instruction Number 9 Year 2000 concerning gender mainstreaming in national development, as one of the strategies to recognize and bring forth gender equality. The instruction provides mandates to all departmental and non-departmental institutions, as well as provincial or municipal governments. In terms of legal substance, many legal bases and socialization have been made available. However, evaluation of the implementation at the level of policies and programs for gender mainstreaming has yet to be optimized. ${ }^{5}$

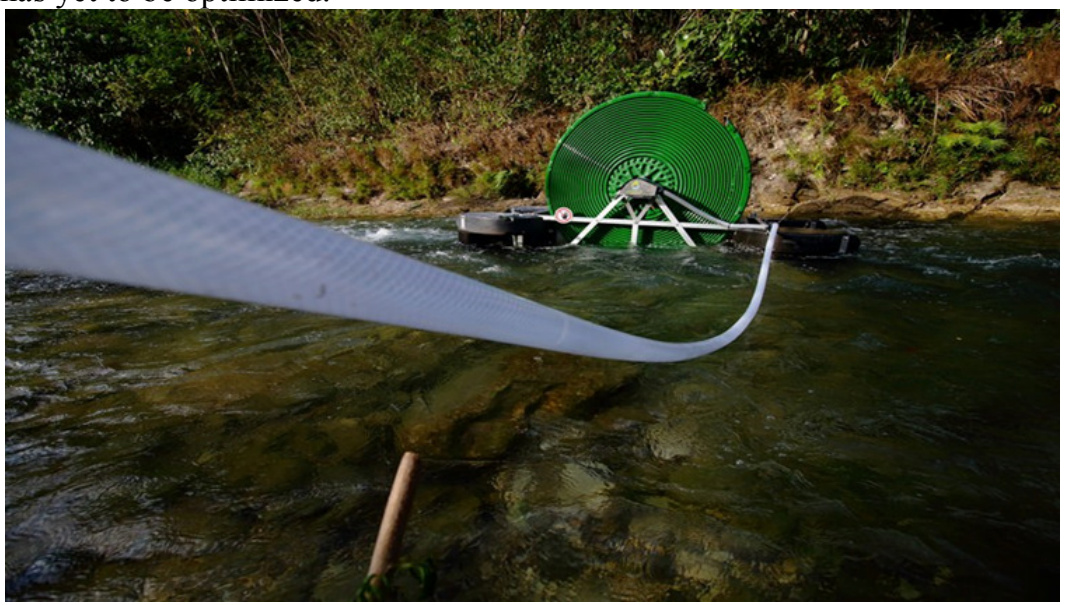

The Barsha pump technology program conducted by Max Waingapu Radio Foundation in collaboration with Delf University, A'qysta and University of Merdeka Malang Indonesia, holds several particular uniqueness, one of which is the water-powered pump technology. Next, the types of methods and guidance as well as payment mechanism for the results of the fields carried out after harvest distinguish this project from those of its predecessors. The rental system applied by the foundation is a scheme created with the obligation for the foundation as the owner of the pump to be responsible for technical issues, namely to install and maintain the pump, and ensure that the water reaches the farmer's fields. ${ }^{6}$

This paper examines to obtain the impacts from the use of Barsha pumps on female farmers' access and control in the financial management mechanism. In addition, it elaborates on women's experiences, opportunities, access, and control in carrying out their roles, both in the private and domestic particularlly on living condition and quality of life.

\section{Research methods}

Purposive sampling was used to determine the sample locations due to the far distance and the similar living conditions of the farmers in various areas. Interview and focus group discussion were used to obtain data. The sample of this study are group of farmers and women farmes due to the pilot project of barsha pump is given to a group of women farmer. From nine group of farmer community, four group of farmers are choosen due to the same condition of farmer community.

\footnotetext{
${ }^{1}$ Moraes, Andrea Ferreira Jacques de. 2013. In Journal of Cleaner Production; 60; 163- 169. Elsevier Ltd.

${ }^{2}$ https://journals.sagepub.com/doi/abs/10.1177/0971852416640639

${ }^{3}$ Quisumbing, A.R., \& Pandolfelli, L. 2010. Promising Approaches to Address the Needs of Poor Female Farmers: Resources, constraints, and interventions. World Development, 38(4), 581-592.

${ }^{4} \mathrm{https}$ ://www.un.org/waterforlifedecade/gender.shtml

${ }^{5} \mathrm{https}: / /$ www.kemenkeu.go.id/sites/default/files/inpres-no.-9-tahun-2000-tentang-pug.pdf

${ }^{6} \mathrm{http}: / /$ kupang.tribunnews.com/2018/08/07/heinrich-dominggus-dengi-ingin-petani-sukses
} 
One approach used to achieve gender equality and justice is by fulfilling gender needs. Sensitive gender approach was used to analyze the following aspects: (1) how men and women use water resources, (2) which party attains fruitful benefits and holds the opportunity to decide policies in all level, (3) who receives benefits from the development of water resources such as knowledge and training, (4) who has the power to take control and (5) whether every woman from different backgrounds receive fair benefits ${ }^{1}$.

\section{B. RESULT AND DISCUSSION}

In general, farmers shows an interest in joining the program offered by Radio Max Waingapu Foundation. Each group of farmers who attain water through the Barsha pump operation supported by the foundation can pay rent as much as $20 \%$ from their total income. Farmers need a start off capital in order to gain availability of seeds and fertilizers. Furthermore, they also need assistance from agents from the agricultural service in addition to market access to sell crops. Female farmers hold only one wish which is to see their children attaining the highest education possible, and such factor drives them to work diligently in the garden. Unfortunately female farmers seldom care or show concerns for their own needs.

Until August 2018 - April 2019, there were already 9 Barsha pump units installed and have been used by some members of the farmer groups.

Villages or locations of Barsha Pumps installation and the number of farmers based on sex in 2018

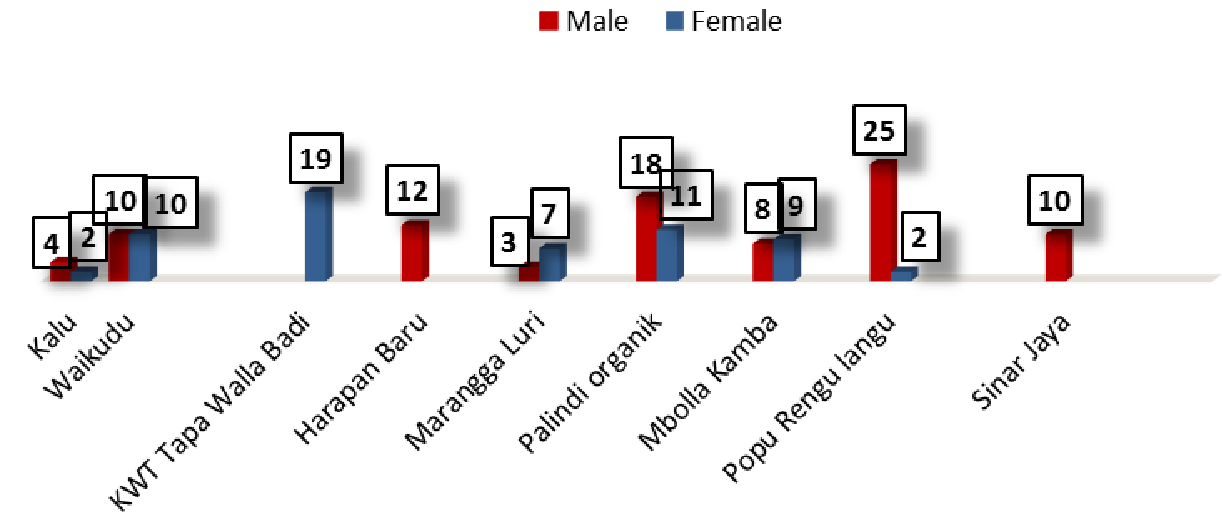

There is a misunderstanding both in society and the government when talking about gender, which is understood only about women. To provide gender understanding, both men and women should show involvements in order to achieve the goals of gender equality between the two sexes. It is highly expected that in the future, study and socialization about gender in environments of farmers can have greater focus so as to provide additional knowledge and understanding for both sexes (male and female farmers) in carrying out their roles, both in the household and in the community. Based on the findings above, an interesting discovery was made. Female farmers have double duties (double burden) and such condition is considered to be very much the norm. Therefore, when inquired regarding obstacles faced by female farmers, they revealed their inability to carry out their roles in the farms because they have babies and children to nurse and nourish. However, this role should not be an obstacle in the first place. Perhaps they essentially only carry out their roles as a whole and an obligation. The task given to female farmers ranges from taking care of the house (cleaning the house, cooking and washing the dishes ), preparing the children and taking care and feeding livestocks (goats and pigsAfter the pump is install women farmer also watering vegetables, and monitoring the pipelines that drain water to the profile tank and to the beds, as well as maintaining the pump. Agricultural farming is done in groups, and the technical process is carried out according to the set schedule, as female farmers also have to work in their respective fields. The direct advantage felt is that they can irrigate their fields and no longer having to use physical energy, thus resulting in more time efficiency. In addition, the presence of financial income can be felt during the dry season.

One of the difficulties faced after the installation of the pumps is pests found attacking the plants. In addition, there was no offered assistance from the agricultural office of the City of Waingapu regarding access to seeds. Agricultural extension agents have never held visits, therefore farmers were required to buy their own seeds on the market at a higher rate. Farmers realized that their obligations with the foundation are only based on an oral consensus and unwritten agreements.

Group of female farners have carried out routine activities such as potluck gatherings involving money and basic goods. The above economic activities have not become cooperatives and only acts as a form of joint

\footnotetext{
${ }^{1}$ Chinkin, C. Gender Mainstreaming in Legal and Constitutional Affairs, 2001, United Kingdom: Commonwealth Secretariat
} 
business activity. After the pump was installed, the farmers collected the harvest one time. They started planting in May and harvested in October 2017. Initially, the female farmers held a role in working on fields that became the test field to attain water from the Barsha pumps, where tasks in caring for the demonstration plot are distributed amongst themselves. Farmers bought plant seeds in the market. Shallots were planted for the first time, and were attacked by pests in the form of caterpillars. Red onion seeds were bought in the form of tubers and seeds. The introduction of plant varieties has not been widely used. The proceeds from the sale of crops at the demonstration plot (15 acres) were divided between 15 members. From the interviewed with the head of women farmer that stated where an individual can receive a revenue worth up to Rp. 400,000 ( \$ ), then Rp. $275,000(\$)$ and the least active group member received Rp. 50,000 (\$) depending on the amount of carried out activities. The fields are generally planted with tomatoes, bok choy, and shallots. The interview revealed as "I go to the market once a week to buy rice, and others, such as tofu and tempe ...."

From the results of interviews with the Radio Max Waingapu Foundation as the manager of the pumps, a number of information was concluded. The mechanism of lease payments made by farmer groups is $20 \%$ of the proceeds from the sale of crops, which are submitted to the foundation through the foundation officers who collect the payments on the locations. Until now, farmer groups have agreed with the payment model mechanism set between them. The agreement was made verbally (unwritten), so mutual trust have been established between the foundation and the farmers. The obligation of farmers during the operation of the pump is to monitor and maintain the pump, and the staffs of the foundation are responsible for fixing and repairing any broken parts. Monitoring is carried out by the foundation twice a month.

Following the operation of the Barsha pumps, the lives of farmers, especially female ones experienced meaningful changes in relation to the harvest of their crops. The pumps allowed farmers to irrigate their fields and produce various types of vegetables to be sold during the dry season which was unseen before the pump installation. This progress gave birth to economical impacts on the farmers' daily lives as it provides a gateway for an income, thus enabling them to occasonally fulfill their few basic household needs, such as meals for family members and additional fundings for their children's school. As interview have been done one of female faremer mention namely Mira "Iam happy now because of installation of bursha pump, I can sell the vegetables to the market and make money so I can buy the household needs in the market such as rice, tahu, tempe an others...."

The payment mechanism to the pump manager, namely the foundation, can be done by a group of farmers. Nevertheless, the financial management payment model needs improvements, such as formulating an agreement to provide protection for farmers in the case of unexpected events, such as crop failure or crop yields that are not optimal due to pest attacks. As commonly known, the pump installation project basically aims to help farmers gain harvests during the dry season. Furthermore, the foundation's obligations as of yet, involves cases of maintenance, such as making repairs in the event of technical damage. The time frame for this obligation to be carried out is still unclear at the moment. Therefore, in the future there needs to be a regulatory mechanism model related to the role of the foundation in pump operation when the number of pump installations increases.

One approach used to achieve gender equality and justice is to meet gender needs, namely practical and strategic needs. In the case of the pump operation, the target is practical needs, because it can be directly felt by farmers. This is an essential necessity, especially for female farmers, to be given access to water and control in financial management after harvest which is something that they never possessed before.

The women and men farmer have decided unanimously to determine the use of water equally, particularly for household needs and farm irrigation. However in the institutional level, not all women and men have equal opportunity to enhance their knowledge and training. The power to take control in decision making process in connection with policy and programs lies in the hand of the head of institution. As a result, it can be concluded that cultural partriachy is a factor that still affects the mind set of people. As mention by the secretary of Agricultural Instistution, she said : "I already in this position several time in some institution in this region, but I never choosen as the head of instituton because Iam a woman. My capability is not less then a man but de to the decision maker in the hand of men asa majority aand the cultural constraint namely patriarchal still very strong influencing, so I ..

It has become increasingly accepted that women should play an important role in water management and that this role could be enhanced through the strategy of gender mainstreaming. The differences and inequalities between women and men influence how individuals respond to changes in water resources management. Understanding gender roles, relations, and inequalities can help explain the choices people make and their different options. Involving both women and men in integrated water resources initiatives can increase project effectiveness and efficiency. ${ }^{1}$

The interesting aspect from the results of this study is that there are findings that show how women farmers are given the opportunity to work on their fields and finally have the ability to manage the payment mechanism

\footnotetext{
${ }^{1}$ https://www.un.org/waterforlifedecade/gender.shtml
} 
by the foundation for their harvests by making payments of $20 \%$ from the sale of their crops. This finding is surprising because it dismissed the notions and perceptions of the community on the capacity of uneducated village people, which up to now has been regarded as people who do not have the ability to carry out payment obligations to managers. This finding showed that if opportunities are given equally between men and women in the field of empowerment, in this case it is the opportunity and access to the pumps installments, the result is equally successful. Female farmers, with their double roles, are able to show tremendous capacity.

\section{CONCLUSION}

The wishes of female farmers in connection with the Barsha pump installation program in areas of their fields are to increase their family's income. The agreement between farmers as Barsha pump users, with the foundation as the pump manager, arrives upon in the form of an obligation for farmers to pay as much as $20 \%$ of the proceeds from the sale of their harvest. After the first harvest, there were already 5 groups that made the payments, and there were those who had not yet made payments due to crop failure. Payments are collected by the manager during visitations to each location

An important impact on the farmers' lives can be observed following the operations of the Barsha pumps. Farmers have received basic income during the dry season therefore enabling them to fulfil the necessities of their family members, especially for their children. This involves the ability to fund their children's education as well as having an improvement of nutrition in their diet, though the latter has not met a standard level.

Women farmers are given the opportunity to work in their fields and finally have the ability to manage the payment mechanism by the foundation for their harvests by making payments of $20 \%$ from crop sales. This finding is surprising as it dismissed the notions and perceptions of the community on the capacity of uneducated village people, which up to now has been regarded as people who do not have the ability to carry out payment obligations to managers. This finding showed that if equal opportunity is given to both men and women in order to instill empowerment, in this case the opportunity and access to the pumps installments, the result is equally successful. Female farmers, with their double roles, are able to show remarkable capacity.

\section{Recommendation}

Research limitation appeared through the findings as it only provides representations of some villagers and have not covered all institutions as of yet. Initially, water pump technology have never been used during prior researches.

Originally, prior research never used water power pump technology and showed limited follow up towards projects. However, this project have shown the rising potentials and credibility of women farmers when given access to water and significant participation in financial management. It provokes many preconceived notions regarding women farmers as uneducated second class citizen lacking in ability to take control and empower their own lives and their family.

A special study and training for the local government offices within Waingapu, Sumba concerning gender mainstreaming is extremely essential to be carried out. In the future, the mechanism of maintenance of the pumps by the foundation with farmers needs to be made in a written / formal agreement model particularly in relation to the rights and obligations of the parties (the foundation as the manager and farmers as the users).

\section{REFERENCES}

1. https://www.kemenkeu.go.id/sites/default/files/inpres-no.-9-tahun-2000-tentang-pug.pdf

2. Asma Luthfi. 2010. Akses dan Kontrol Perempuan Petani Penggarap Pada Lahan Pertanian PTPN IX Kebun Merbuh. Komunitas 2 (2) (2010): 74. http://Journal.unnes.ac.id/nju/index.php/komunitas

3. Sri Walny Rahayu dkk. 2009. https://www.academia.edu/29818839/analisis studi pada instansi pemerintah sektor pertanian Province Aceh. Accessed on 30 September 2018.

4. Indrayanti, Kadek. 2017. Independent Lecturer's Research.

5. Hastuti dan Respati, Dyah. (2009). Model Pemberdayaan Perempuan Miskin Berbasis Pemanfaatan Sumberdaya Perdesaan Upaya Pengentasan Kemiskinan di Perdesaan (Studi di Lereng Merapi Daerah Istimewa Yogjakarta). Jurnal Universitas Negeri Yogjakarta.

6. Moraes, Andrea Ferreira Jacques de. 2013. In Journal of Cleaner Production; 60; 163- 169. Elsevier Ltd.

7. http://kupang.tribunnews.com/2018/08/07/heinrich-dominggus-dengi-ingin-petani-sukses

8. https://undpid.exposure.co/pompa-air-yang-mengubah-kehidupan-di-sumba-timur

9. http://maxfmwaingapu.com/2017/08/pompa-barsha-bantu-petani-di-musim-kemarau/

10. Chinkin, C. Gender Mainstreaming in Legal and Constitutional Affairs, 2001, United Kingdom: Commonwealth Secretariat.

Laws

Law No. 25 of 2000 concerning National Development Program. 
Presidential Instruction No. 9 of 2000 concerning Gender Mainstreaming.

State Decree of the Ministry of Woman Empowerment Number 3/SK/MENEG.PP/VI/2001 concerning the Guidelines on the Stipulation of Minimum Service Standard for Woman Empowerment in Province and Municipal/City Level as an Autonomous Region.

State Decree of the Ministry of Domestic Affair Number 132 of 2003 concerning the Guidelines for the Implementation of Gender Mainstreaming for Development in Regions that Instructs Every Government Institutions to Implement Gender Mainstreaming. 